\title{
RASIP1 wt Allele
}

National Cancer Institute

\section{Source}

National Cancer Institute. RASIP1 wt Allele. NCI Thesaurus. Code C98185.

Human RASIP1 wild-type allele is located in the vicinity of 19q13.33 and is approximately $20 \mathrm{~kb}$ in length. This allele, which encodes ras-interacting protein 1, plays a role in signaling. 